\title{
Social Correlates of Church Attendance in Three European Catholic Countries
}

\author{
Brian Conway
}

Received: 16 March 2012/Accepted: 10 September 2012/Published online: 21 September 2012

(C) Religious Research Association, Inc. 2012

\begin{abstract}
The sociology of religion literature recognizes secularization as an uneven process complicated by individual and country-level variables. However, considerably less attention has been given to how correlates of church attendance vary across divergent settings within a single religious denomination. Employing recent data from Belgium, Ireland, and Slovenia, we test whether the belief, ideological support for the church, and religious commitment correlates of religious behaviour are similar across these Catholic countries and whether there are any remaining country effects influencing church attendance. The results of ordered logit regression models show, on the one hand, the correlates of church attendance are basically the same across the three countries and, on the other, that country effects remain even when controlling for the key explanatory variables and other covariates. These empirical findings suggest the need to develop a more contextualbased understandings of secularization, focusing on the influence of cultural factors operative in nationally-specific settings.
\end{abstract}

Keywords Church attendance $\cdot$ Secularization - Catholic countries · Comparative Surveys

\section{Introduction}

While there is ample research in the sociology of religion literature about secularization as an uneven process that is complicated by individual and countrylevel variables (Gorski and Altinordu 2008; Swatos and Olson 2000), relatively few studies have examined the correlates of church attendance across diverse settings within a single religious denomination.

B. Conway $(\square)$

Department of Sociology, National University of Ireland Maynooth, Maynooth, Co. Kildare, Ireland e-mail: brian.conway@nuim.ie 
Sociological studies of secularization involving the quantitative use of largescale social survey data tend to fall into three broad categories: large $\mathrm{N}$, theory construction studies (Norris and Inglehart 2004), moderately large N studies testing a particular theory (Kelley and De Graaf 1997), and two or three country case studies involving a comparative historical focus (Gautier 1997). The task of delving deeper into the characteristics of national contexts is made difficult by the sheer number of nations included in the first two kinds of investigations. The third category involves putting forward a qualitative historical account of each country's development as a basis for understanding the factors influencing individual-level religious identity, a research strategy that comes closest to the approach followed here, with reference to the three Catholic countries of Belgium, Ireland, and Slovenia.

These different studies, and the sociology of religion literature more broadly, rely on different understandings of the concept of secularization. Indeed, secularization has a wide variety of meanings ranging from declining levels of church attendance and religious belief, to the diminution of institutional influence and religious authority, through to the rise of secular perspectives in science, politics, education and other areas of social life (Chaves 1994; Tschannen 1991; Gorski 2003). These varying meanings imply that secularization operates at different levels of the social structure from the individual level of analysis right up to the organizational and societal levels (Dobbelaere 1999). Sociologists have sought to generalize the empirical scope of these conceptual understandings, but religious change may be too complex and historically contingent in unique regional settings, to allow for such general application. In the present study, secularization is analyzed at the individual-level and is understood to mean a reduction in religious service attendance, commitment to religious beliefs, and confidence in church moral position-taking among devotees.

We begin by providing a rationale for comparing the three countries and give a brief historical background of each. To provide a conceptual framework for the analysis we then introduce and elaborate upon the literature on the social correlates of religious behavior and participation, focusing on belief, ideological support for the church, and religious commitment correlates. Following this, the data and measures as well as the characteristics of the country samples are described. The theoretical framework motivates hypotheses about the specific influence of the three correlates on church attendance and these are tested using an ordered logit regression analysis. The conclusion summarizes the empirical and theoretical contribution of the study.

\section{Comparing the Three Countries}

Comparative research on religion has usefully categorized wider Europe in denominational terms by distinguishing between Catholic, Protestant, and mixed countries (Martin 1978, 1994). Within the Catholic cluster, Belgium, Ireland, and Slovenia were chosen as comparison countries because they represent traditionally 
Table 1 Comparing the three Catholic countries, 1940-2012

\begin{tabular}{|c|c|c|c|}
\hline Variable & Belgium & Ireland & Slovenia \\
\hline Modal type of catholicity & Pillar & Monopoly & Suppression \\
\hline Nature of secularization ${ }^{\mathrm{a}}$ & Spontaneous & Spontaneous & $\begin{array}{l}\text { Enforced and } \\
\text { partial spontaneous }\end{array}$ \\
\hline $\begin{array}{l}\text { Major forces } \\
\text { of secularization }\end{array}$ & Modernization & Modernization & $\begin{array}{l}\text { State repression and } \\
\text { partial modernization }\end{array}$ \\
\hline Church-state nexus & Co-operation & Co-operation & Partial conflict \\
\hline Macro political history ${ }^{\mathrm{b}}$ & Continuous democracy & Continuous democracy & Regime change \\
\hline
\end{tabular}

${ }^{a}$ The differentiation between spontaneous and enforced secularization comes from Meulemann (2004)

$\mathrm{b}$ The distinction between continuous democracy and regime change comes from Fishman and Jones (2007)

Catholic countries but, at the same time, have quite different historical backgrounds and experiences of Catholicism ${ }^{1}$ (see Table 1).

Belgium, Ireland, and Slovenia are all small European societies and economies, Belgium is located at the core, Ireland at the periphery, and Slovenia at the eastern border. Importantly they are all countries with historically strong Catholic majorities and with a small proportion of their respective populations comprised by non-Catholics and non-Christians. In the 2008 wave of the European Values Survey (EVS), $89 \%$ of the Belgian sample, $94 \%$ of the Irish sample, and $93 \%$ of the Slovenian sample self-identified as Roman Catholics.

Belgium is an example of a stable continuous democracy but, compared to Ireland, has a considerably longer history of independence going back to 1830 (Houtart 1970; Martin 1978; Fox 1982). Belgium belongs to the pillar category of Catholicism (Dobbelaere 1995; Martin 1978). By pillarization is meant the organization of societal institutions (schools, hospitals, political parties, media etc.) based on (secular and religious) ideological interests. The Belgian case is complicated by the fact of its bipolar regional division between a predominately Dutch or Flemish-speaking Flanders region in the north and a predominately French-speaking Walloon region in the south. This linguistic and regional

\footnotetext{
${ }^{1}$ In this study, larger and better-known Catholic countries such as France, Italy, and Poland are passed over. These cases are also suitable for comparison but owing to the relative neglect of smaller Catholic countries in prior comparative research on Catholicism (Manuel et al. 2006; Gannon 1988) we chose to investigate variation across these three regional settings. To cite two examples, a recent edited volume investigating the relationship between religious and political authority in international Catholicism (Manuel et al. 2006), included eleven case studies of national churches in the global church, and of these, only three represented small Catholic countries. In Gannon's earlier work, just two of seven case studies representing European Catholicism consisted of a small Catholic country (Belgium and the Netherlands), the remainder focusing on larger contexts (Gannon 1988). In addition, previous comparative work on Catholicism tends to suffer from a "scaling up" problem, by focusing heavily on describing and analyzing church-state interactions, with the result that somewhat less attention has been given to accounting for variation in religious beliefs and practices or institutional strength, such as trends in the Catholic workforce, across different national contexts. A further limitation of earlier studies of Catholicism is that they tend to eschew the direct comparison of cases, a weakness we attempt to address in this study.
} 
nationalism cleavage is overlaid with other social divisions including religion and social class (Dobbelaere and Voyé 1990; Martin 1978; Fox 1982).

From the 1960s, and owing mainly to increased modernization, Belgian Catholicism weakened in terms of its institutional strength but also in terms of the commitment of devotees. As in the Irish case, the church in Belgium experienced a significant reduction in organizational recruitment in the post-Vatican II era. The peak year of vocations to the diocesan priesthood in Belgium, 1949, was earlier than in Ireland and the decline was underway well before Vatican II (Fishman and Jones 2007). Other indicators of Catholic commitment such as weekly church attendance also declined especially in the 1967-1973 time period. Generational experiences have exerted a strong influence on religious belonging, the drop off in church attendance and other indicators of religiosity were more pronounced among young people than older generations (Dobbelaere 1988; Fox 1982).

Turning to the Irish case, a strong historical linkage developed between national and religious identity owing to a long history of religious persecution under English colonization (Fahey 1992). The newly independent Irish state, created in 1921, looked to the Catholic Church for symbolic legitimation and, in turn, afforded the church an important role in social welfare provision and lent its support to Catholic ethics. Catholicism in Ireland belongs to the monopoly category owing to the church's symbolic dominance, and virtual monopoly status concerning morality, in Irish society (Inglis 1998).

As in Belgium, the post-Vatican II experience of the Catholic Church in Ireland involved decline in Catholic vocations, and from a very high level. While the decline in vocations to the diocesan priesthood took hold in the late 1950s, the peak year was 1959 (Fishman and Jones 2007), it continued after Vatican II. This suggests that while the council may not have been a direct causal factor in the decline, by creating more equal clergy-laity relations it had the unintended consequence of reducing the rewards, such as social status, associated with becoming a member of the church's male workforce and, hence, its appeal as an organization to join (Stark and Finke 2000).

From the 1960s, Irish society underwent a process of modernization, which was accompanied by increasing secularization. Church attendance levels ${ }^{2}$ after Vatican II held up more strongly in Ireland than in Belgium and did not begin to go into sharp decline, especially among the young sectors of the population, until the 1980s and 1990s (Fahey 1992). Historically, church-state relations in the Irish case have been characterized by close co-operation, but since the 1970 s, government policies have increasingly challenged the church's moral agenda, in relation to divorce, abortion, contraception and more recently, Catholic schooling and same-sex marriage, and stoked church-state tensions (Keogh 2007).

Slovenia represents a Catholic country in Eastern Europe and has a long Catholic tradition going back to its early Christianization in the sixth century (Črnič and

\footnotetext{
${ }^{2}$ Some disagreement exists among scholars of Catholicism concerning the causes of the church attendance decline (mainly in relation to the US case). Two prevalent explanations apart from the influence of Vatican II are the impact of the 1968 Papal encyclical on birth control, Humanae Vitae (Greeley 2004) and the interaction of the sexual revolution with the feminist movement and youth subculture (Hoge 1986).
} 
Lesjak 2003; Dolenc 1994). As in Ireland, it had an historical experience of church suppression during which a strong linkage was forged between religious identity and national belonging. Because of its recent history of church suppression under communism, ${ }^{3}$ Slovenia falls into the suppression category of Catholicism.

In the communist era (spanning the early 1940s to 1991), some state activities, such as the funding of faith communities and the granting of autonomy in relation to episcopal appointments, did not involve church suppression while others did and, hence, church-state relations in Slovenia may be characterized in terms of partial conflict (Vidić 1962; Cava 1997). The suppression that did take place took different forms ranging from state appropriation of the church's property assets and the imprisonment of church personnel, to restrictions on religious education and the breaking of diplomatic relations with the Holy See (Smrke and Rakar 2006; Ramet 2002). While this suppression of religious activity, or "enforced secularization" (Meulemann 1994, p. 49), played an important role in the country's secularization, in contrast to the two other cases, it is also the case that Slovenia underwent considerable socio-economic modernization, industrialization, urbanization and educational expansion, during and after its communist era (Dolenc 1994; Fiamengo 1972; Ramet 2002; Marko 1993; Ramet and Fink-Hafner 2006) and that this "spontaneous secularization" (Meulemann 1994, p. 49) also contributed to a decline in religious vitality.

In the 1960s, the Catholic Church enjoyed a plentiful supply of male clergy (Ramet 1985) and provided few opportunities for lay activism among the Catholic faithful (Ramet 2002). After Vatican II, the church faced growing legitimacy challenges and, in the 1970s and 1980s, church-state clashes arose in relation to contentious issues such as the place of Marxism in school curricula, the state's human rights record, and discrimination against Catholics in government employment (Dragos 2009; Ramet 2002). After independence, political debate about the role of religion in the public square continued to challenge the church's legitimacy, particularly in relation to the provision of Catholic schooling (Ramet 2002). New callings to the Catholic female workforce began to go into decline in the 1940s, two decades prior to Vatican II, but experienced some numerical growth in the 1960s, and then began to decline again from the 1970s onwards (Bezjak 2012). Trends in other indicators of religious commitment, such as belief in Christian concepts such as a personal God and life after death, began to increase in Slovenia in the 1990s as the country underwent regime change by moving away from communism toward democratic politics and governance (Greeley 2003; Smrke 2008).

This schematic account of the quite diverging historical backgrounds of Belgium, Ireland, and Slovenia suggest there are a number of good theoretical reasons for expecting church attendance, a key precept of the Catholic Church, to vary across the three regional settings of Catholicism. One reason relates to religious belief.

\footnotetext{
${ }^{3}$ Communism refers to an ideology and a form of social, political and economic organization whose 'negative' characteristics include the rejection of liberal capitalistic models and the suppression of civil society activity. It is also characterized by a virtual monopoly by the Communist Party of the state's economy and polity and the Party's capillary power extending to all areas of social life. Slovenia's communist and socialist past differentiates it from other Eastern European societies, since Yugoslavia threw off Soviet Union occupation and influence in 1948 (Bezjak 2012).
} 
Although the data used in this study lacks measures of specifically Catholic belief orthodoxy and employs instead more general measures of Christian orthodoxy such as belief in God, sin, and life after death, past research suggests that belief orthodoxy in one religious tradition may be influenced by the numerical strength of other religious groups in the national local environment (Stark 1998; Jelen and Wilcox 1998). Specifically, in societies such as Belgium, with somewhat higher levels of non-Catholics and non-Christians than in Ireland and Slovenia, the presence of non-Christians may adversely influence the orthodoxy of Catholics by weakening the truth claims of the Christian faith or, alternatively, by acting as a source of group resistance to Christian identity, may bolster Catholics' devotion to general Christian beliefs.

Different experiences across the three samples in historic church-state interactions represent a second reason for expecting variation in church attendance. In each country the Catholic Church has played an important prophetic leadership role, in Belgium in relation to the organization of pillar social organizations, in Ireland in regard to political violence and the politics of the family, and in Slovenia in respect of the communist state, but of the three countries, the church's socio-political critique has perhaps been strongest in Slovenia. One might expect this prophetic leadership to contribute to a bolstering of the church's standing among the general populace in relation to responding to spiritual and social problems and needs.

A third reason for expecting variation in church attendance across the three countries has to do with socio-economic conditions. Ireland and Belgium are characterized by the highest levels of socio-economic and human development, defined as the ability of members of the general populace to live fulfilling lives in which their basis needs are met, while Slovenia has the lowest (United Nations Development Programme 2011). This can impact religious behavior as prior research suggests that levels of human development produce different levels of "existential security" which, in turn, leads to increases or decreases in religious belief and practice (Norris and Inglehart 2004).

\section{Theoretical Orientations and Research Hypotheses}

The influence of three correlates of religious behavior-belief, ideological support for the church, and religious commitment variables (Bibby and Brinkerhoff 1974; Cornwall 1987) are investigated in this study, beginning first with belief.

\section{Belief}

Whether one is a religious believer or not is shaped by the social context and this extends from one's family, especially through the influence of parents, to the wider national environment. Parents transmit their beliefs to the next generation by teaching their children how to pray, by placing religious objects in the home, and by attending church themselves. The religiosity of the local environment, the religious (or secular) values of people in one's social networks, for example, may augment or diminish this family-level religious socialization (Kelley and De Graaf 1997). 
One consistent finding from the literature is that people who are believers are more likely to practice their religion than those who are not believers (Aarts et al. 2008; Cornwall 1989; Bibby and Brinherhoff 1974). There is not a simple or straightforward relationship between belief and practice, however, and some debate exists about which comes first and the direction of causal influence. Some believers attend church services and engage in religious practice such as prayer while others engage in few, if any, religious activities. At the same time, some people who participate in religious activities may not believe in all or some of the major beliefs of their church or may believe in general Christian orthodoxy but not in the orthodoxy of their specific faith tradition. In the case of Catholics, for example, devotees may believe in generic Christian ideas concerning God and heaven but not in distinctly Catholic beliefs concerning abortion, artificial contraception, weekly Mass attendance, and the transubstantiation of the Eucharist during the Mass. Usually, though, belief and practice go together at least to some degree.

Prior research also suggests that the relationship between belief and practice may vary across different religious categories. For example, because of the more individualistic orientation of Protestantism compared to Catholicism, Catholics should be more likely than Protestants to attend church (Lüchau 2007). Lüchau found a strong connection between belief and practice in his study of Denmark, Germany and Italy but found that the expected weak relationship between church attendance and Protestantism did not exist (Lüchau 2007). Highlighting potential empirical vulnerabilities in Grace Davie's oft-cited concept of believing without belonging, Aarts and colleagues found that Christian belief at the individual-level is not as out of sync with practice as is often assumed (Aarts et al. 2008).

We thus formulate and test Hypothesis 1: We hypothesize that the effect of belief on church attendance will differ across the three countries in accordance with variation in belief orthodoxy.

\section{Ideological Support}

Apart from belief, religious participation and belonging is also potentially shaped by one's ideological support of churches (Karpov 1999). People who have a high level of confidence in churches and who feel that religious institutions provide an important source of guidance to them about their everyday spiritual and moral lives are more likely to be active religiously than people who do not. People's confidence in the church, in turn, is conditioned by church-state sentiments and relations in a given society. In some societies, churches enjoy strong state support either in ideological or material terms (or both) while in other societies church and state are ideologically opposed (Need and Evans 2001). In the case of the latter, churches can act as important vehicles for expressing opposition to state repression through the symbolic resources, religious narratives motivating political action, for example, or material resources, church buildings as meeting places for state dissidents, at their disposal whereas in the former churches are less likely to take public stands opposing state activity. 
Ideological support for churches also depends upon the extent to which people feel they have credibility and legitimacy when it comes to taking public stands about important social and moral issues of the day (Dillon 1996). Churches that are able to legitimize their public political and moral claims-making by appealing to such things as religious ethics, human rights codes, and national myths are more likely to exert influence on public opinion. Churches that act in ways that are incongruent with these bases of authority are more likely to lack widespread public legitimacy.

We thus formulate and test Hypothesis 2: We hypothesize that the effect of ideological support on church attendance will differ across the three countries in accordance with variation in church sociopolitical leadership.

\section{Religious Commitment}

A final explanation for religious behavior is religious commitment (Cornwall 1989). This has to do with the salience or not of religion in one's life and represents the subjective, personal and affective element of religiosity. This is a variable that comes between belief and behavior and helps explain why religious beliefs and behaviors sometimes do not go together. One may believe in God but if this does not mean one is committed to this belief, one is unlikely to engage in religious behaviors to validate it. Certain social practices tend to flow, then, from strong levels of commitment to a belief item that involves trade-offs or opportunity costs in relation to other behaviors. But prior research further suggests that the meaning and social practice components of religiosity go together, how active people are in their religious group tends to strongly influence the salience of their faith (Roberts and Davidson 1984).

General socio-economic conditions also tend to exert a strong bearing on the degree of one's religious commitment though scholars disagree about the nature of the relationship between life conditions and religious participation (Tabak and Mickelson 2009). Some studies suggest that religiosity has a negative impact on important life conditions, experiences and outcomes (Schnittker 2001) while a larger body of research suggests it has a positive effect (Mooney 2009; Schieman 2010; Tabak and Mickelson 2009). In societies with poor socio-economic conditions, people's daily lives are often characterized by high levels of uncertainty, instability or difficulty, or lack of "existential security" (Norris and Inglehart 2004), and in these conditions religious commitment tends to be greater because challenging life experiences and situations, ranging from material disadvantage and mental distress to discrimination and the absence of a political and civil society voice, tend to contribute to the bolstering of people's commitment to their faith as individuals draw on their religious identities to make sense of these difficult situations. The content of religious narratives, the collective worship experience, the physical setting of religious services, or the social ties devotees develop in them, can all help people to do this (Mooney 2009; Schieman 2010; Tabak and Mickelson 2009).

We thus formulate and test Hypothesis 3: We hypothesize that the effect of religious commitment on church attendance will differ across the three countries in accordance with variation in socioeconomic conditions. 


\section{Socio-demographic Controls}

Because past research links a number of socio-demographic variables such as age, gender, education, employment status, and political ideology to religious identity (Roberts and Davidson 1984), we control for their influence on church attendance. We included age squared in the models in order to test for curvilinear age effects.

\section{Data, Variables and Measures}

\section{Sample}

The individual-level data for this analysis come from the 2008 wave of the EVS. The country sample sizes were variable: 1,509 for Belgium, 1,013 for Ireland and 1,366 for Slovenia, constituting a total sample of 3,888 respondents. Table 2 reports the descriptive statistics for the variables and Table 3 summarizes all the variables and their definitions. All the analyses were carried out in Stata.

\section{Explanatory Variables}

For the belief and church answers needs variables, we constructed an index of these by creating a new variable representing the average of the number of domains each respondent believed in or felt the church provided answers to. ${ }^{4}$ We reverse coded the importance of religion and church attendance variables to make their interpretation more intuitive.

\section{Descriptive Characteristics of the Three Samples}

The Irish sample is somewhat younger than the Belgian and Slovenian samples with a mean age of 45.70 years. In all three countries, females represent a higher proportion of the sample than males and being married is the most frequent marital status. Irish respondents have more children than either Belgian or Slovenian respondents with a mean number of children of 2.09 compared to 1.61 for Belgian respondents and 1.48 for Slovenian respondents. Thirty-two per cent of the Belgian sample and $31 \%$ of the Irish sample have some higher education compared to $19 \%$ in the Slovenian sample. With respect to employment status, $53 \%$ of the Belgian sample is employed compared to 55 and $51 \%$ of the Irish and Slovenian samples. Slovenians report the lowest scores on the political ideology scale and a stronger orientation towards left-wing ideology compared to the Belgian and Irish samples.

\footnotetext{
${ }^{4}$ While the political claims-making of national hierarchies tends to preclude making specific recommendations to government concerning public policy and instead operates at a more general level as outlined in Catholic social teaching, through its various agencies serving the poor and needy, the Catholic Church seeks to address, in a concrete way, current social problems. The church provides answers to social problems indicator may thus be understood as an indirect measure of public support for Catholic social activism.
} 
Table 2 Descriptive statistics of variables (st. dev. in parentheses) across the three samples

\begin{tabular}{|c|c|c|c|}
\hline Variable & Belgium & Ireland & Slovenia \\
\hline \multicolumn{4}{|l|}{ Control variables } \\
\hline Age & $46.99(17.46)$ & $45.70(17.68)$ & $48.53(18.11)$ \\
\hline Gender & $.48(.49)$ & $.40(.49)$ & $.45(.49)$ \\
\hline \multicolumn{4}{|l|}{ Marital status } \\
\hline Not married & $.39(.48)$ & $.49(.50)$ & $.39(.48)$ \\
\hline Children & $1.61(1.47)$ & $2.09(2.03)$ & $1.48(1.15)$ \\
\hline \multicolumn{4}{|l|}{ Education } \\
\hline No formal education & $.02(.14)$ & $.02(.14)$ & $.03(.18)$ \\
\hline Some primary education & $.09(.28)$ & $.14(.34)$ & $.19(.39)$ \\
\hline Some secondary education & $.56(.49)$ & $.52(.49)$ & $.57(.49)$ \\
\hline Some higher education & $.32(.46)$ & $.31(.45)$ & $.19(.39)$ \\
\hline \multicolumn{4}{|l|}{ Employment status } \\
\hline Employed & $.53(.49)$ & $.53(.49)$ & $.51(.49)$ \\
\hline Not employed & $.46(.49)$ & $.46(.49)$ & $.48(.49)$ \\
\hline Political ideology & $5.06(1.88)$ & $5.82(1.89)$ & $5.00(2.00)$ \\
\hline \multicolumn{4}{|l|}{ Explanatory variables } \\
\hline Belief & $.41(.34)$ & $.75(.32)$ & $.42(.36)$ \\
\hline \multicolumn{4}{|l|}{ Ideological support } \\
\hline Confidence in church & $1.90(1.23)$ & $2.29(.95)$ & $2.07(1.03)$ \\
\hline Church answers needs & $.33(.36)$ & $.46(.40)$ & $.42(.39)$ \\
\hline \multicolumn{4}{|l|}{ Religious commitment } \\
\hline Comfort from religion & $.42(.49)$ & $.75(.43)$ & $.55(.49)$ \\
\hline Importance of religion & $1.24(.98)$ & $1.86(.98)$ & $1.31(.97)$ \\
\hline \multicolumn{4}{|l|}{ Dependent variable } \\
\hline Church attendance & $2.48(1.83)$ & $4.40(2.00)$ & $3.19(1.94)$ \\
\hline
\end{tabular}

Source EVS 2008

Overall, there are similarities and differences in the country samples in terms of their socio-demographic characteristics.

\section{Multivariate Analysis of Church Attendance}

The two empirical questions guiding this paper are: (1) to what extent does the effect of the three explanatory variables on church attendance differ across the three countries, and; (2) to what extent do country differences in church attendance remain that are not accounted for by the three explanatory variables and other covariates? To answer the first question, we carried out a multivariate analysis in which we estimate the influence of three explanatory variables on the dependent variable separately in each country. To answer the second question, we pooled the data from the three countries and included country as a covariate as well as 
Table 3 Variables and definitions used in the analyses

\begin{tabular}{ll}
\hline Variable & Definition \\
\hline Control variables & \\
Socio-demographic & \\
Age & In years \\
Gender & $1=$ men \\
Marital status & $1=$ married, $0=$ not married \\
Children & Number of \\
Education & Highest level of education \\
& $0=$ no education, $1=$ some primary education, $2=$ some secondary \\
& education, $3=$ some higher education \\
Employment status & $1=$ employed, $2=$ not employed \\
Political ideology & "In political matters, people talk of 'the left' and 'the right'. How would you \\
& place your views" \\
Explanatory variables & Measured on scale: $1=$ left, 10 = right \\
Belief & \\
God & Which, if any, of the following do you believe in? God, hell, sin, and life \\
Hell & after death \\
Sin & $1=$ yes, $0=$ no \\
Life after death & \\
Ideological support of the church
\end{tabular}

Confidence in churches

"I am going to name a number of organizations. For each one could you tell me how much confidence you have in them" churches

Measured on scale: $0=$ none at all, $3=$ a great deal

Church answers spiritual needs

"Generally speaking, do you think the churches in your country are giving adequate answers to people's spiritual needs?"

$1=$ yes, $0=$ no

Church answers moral

"Generally speaking, do you think the churches in your country are giving problems adequate answers to moral problems and needs of the individual?"

$1=$ yes, $0=$ no

Church answers social

"Generally speaking, do you think the churches in your country are giving problems adequate answers to the social problems facing our country today?"

$1=$ yes, $0=$ no

Religious commitment

Comfort from religion Do you find that you get comfort and strength from religion or not?

$1=$ yes, $0=$ no

Importance of religion How important is religion in your life?

Measured on scale: $0=$ not at all important at all, $3=$ very important

Dependent variable

Church attendance

"Apart from weddings, funerals and christening, how often do you attend religious services these days?"

Measured on scale: $1=$ never practically never, $7=$ more than once a week 
interaction terms. We also ran a model estimating the influence of the sociodemographic control variables on the dependent variable (see Table 4).

Turning to the influence of the explanatory variables on church attendance (see Table 4), and controlling for the influence of the socio-demographic variables, we expected, as set forth in Hypothesis 1, that the influence of belief on church attendance would vary among the three societies. Table 4 evaluates this hypothesis by presenting ordered logit regression co-efficients for each country separately. As Table 4 makes clear, belief has statistically significant (at the .001 level) and positive effects in all three countries. This finding went against our expectations.

Hypothesis 2 predicted that the influence of ideological support of the church should also vary across the samples. As with belief, the ideological support for the church co-efficients were unexpectedly positive and significant in all three countries.

Our third hypothesis predicted that the influence of religious commitment on church attendance would differ across the three countries. A glance at Table 4 shows that the two measures of religious commitment reach a high level of statistical significance (at the .001 level) with respect to all three cases but that the importance of religion variable has a positive effect on church attendance and the comfort from religion variable a negative effect. This does not provide support for hypothesis 3 . The negative co-efficient for the comfort from religion variable is surprising and may be related to the moderately high correlation between the variables $(r=-.60)$, which can have the effect of pushing one variable to have the opposite sign to the other.

It is likely though that there is some residual variation in church attendance that is not captured by the variables included in the separate country models. To capture these national effects we estimated pooled sample models, which included country effects as well as interactions between country and the age covariate (see Table 5). We included an interaction term for age as one might expect that older respondents would show the hypothesized effects in Slovenia and because, as noted earlier, the reduction in church attendance appears to have been more pronounced among the young in Belgium and Ireland. The results for these models are presented in six models beginning with country effects only followed one at a time by variables representing each explanatory variable, and then adding interaction terms, first for country with age and, then, for country with the explanatory variables. In these models Slovenia is the comparison country. The results show a residual country effect and that the covariates influence church attendance differently across the country samples.

Model 1 shows that compared to Slovenian respondents, Belgian respondents are less likely to attend church and Irish respondents are more likely to attend church. As variables are added one at a time, we notice that country effects are not significantly reduced with the exception of Model 6 in the case of Belgium. Indeed, the influence of Belgium, in comparison to Slovenia, tends to increase, especially in Model 3. Models 3-5 add each of the explanatory variables one at a time and when examined individually in these models each of the measures has statistically significant effects.

There are also some differences in the way church attendance is influenced across countries, even when controlling for the socio-demographic variables. To 
Table 4 Ordered logit models of church attendance across the three samples

\begin{tabular}{|c|c|c|c|}
\hline Variable & Belgium & Ireland & Slovenia \\
\hline \multicolumn{4}{|l|}{ Control variables } \\
\hline Age & $\begin{array}{l}-.02 \\
(.01)\end{array}$ & $\begin{array}{l}-.008 \\
(.02)\end{array}$ & $\begin{array}{l}.04 * \\
(.02)\end{array}$ \\
\hline $\mathrm{Age}^{2}$ & $\begin{array}{l}.00 * \\
(.00)\end{array}$ & $\begin{array}{l}.00 \\
(.00)\end{array}$ & $\begin{array}{l}-.00 * \\
(.00)\end{array}$ \\
\hline Gender & $\begin{array}{l}-.07 * \\
(.10)\end{array}$ & $\begin{array}{l}-.29^{*} \\
(.14)\end{array}$ & $\begin{array}{l}-.29 * \\
(.11)\end{array}$ \\
\hline Not married & $\begin{array}{l}-.39 * * \\
(.12)\end{array}$ & $\begin{array}{l}-.38^{*} \\
(.15)\end{array}$ & $\begin{array}{l}.24 \\
(.15)\end{array}$ \\
\hline Number of children & $\begin{array}{l}.10 * \\
(.04)\end{array}$ & $\begin{array}{l}-.07 * \\
(.04)\end{array}$ & $\begin{array}{l}.26^{* * *} \\
(.07)\end{array}$ \\
\hline \multicolumn{4}{|l|}{ Education } \\
\hline Some primary education & $\begin{array}{l}.01 \\
(.39)\end{array}$ & $\begin{array}{l}-.34 \\
(.68)\end{array}$ & $\begin{array}{l}.41 \\
(.38)\end{array}$ \\
\hline Some secondary education & $\begin{array}{l}-.13 \\
(.36)\end{array}$ & $\begin{array}{l}-.64 \\
(.67)\end{array}$ & $\begin{array}{l}.17 * \\
(.37)\end{array}$ \\
\hline Some higher education & $\begin{array}{l}.32 \\
(.41)\end{array}$ & $\begin{array}{l}-.56 \\
(.68)\end{array}$ & $\begin{array}{l}-.18 \\
(.39)\end{array}$ \\
\hline Employed & $\begin{array}{l}-.28^{* *} \\
(.12)\end{array}$ & $\begin{array}{l}-.02 \\
(.16)\end{array}$ & $\begin{array}{l}-.16 \\
(.14)\end{array}$ \\
\hline Political ideology & $\begin{array}{l}.16^{* *} \\
(.02)\end{array}$ & $\begin{array}{l}.24 * * \\
(.04)\end{array}$ & $\begin{array}{l}.31 * * * \\
(.03)\end{array}$ \\
\hline \multicolumn{4}{|l|}{ Explanatory variables } \\
\hline Belief & $\begin{array}{l}1.11^{* * *} \\
(.21)\end{array}$ & $\begin{array}{l}1.37^{* * *} \\
(.32)\end{array}$ & $\begin{array}{l}1.23^{* * *} \\
(.25)\end{array}$ \\
\hline \multicolumn{4}{|l|}{ Ideological support } \\
\hline Confidence in church & $\begin{array}{l}.13^{*} \\
(.05)\end{array}$ & $\begin{array}{l}.19^{*} \\
(.09)\end{array}$ & $\begin{array}{l}.21^{* *} \\
(.07)\end{array}$ \\
\hline Church answers needs & $\begin{array}{l}.80 * * * \\
(.16)\end{array}$ & $\begin{array}{l}1.34 * * * \\
(.24)\end{array}$ & $\begin{array}{l}.78 * * * \\
(.20)\end{array}$ \\
\hline \multicolumn{4}{|l|}{ Religious commitment } \\
\hline Comfort from religion & $\begin{array}{l}-.93 * * * \\
(.14)\end{array}$ & $\begin{array}{l}-1.20 * * * \\
(.23)\end{array}$ & $\begin{array}{l}-.66^{* * * *} \\
(.17)\end{array}$ \\
\hline Importance of religion & $\begin{array}{l}.83^{* * * *} \\
(.08)\end{array}$ & $\begin{array}{l}.64 * * * \\
(.11)\end{array}$ & $\begin{array}{l}1.01^{* * *} \\
(.10)\end{array}$ \\
\hline Constant 1 & 1.35 & .37 & 3.87 \\
\hline Constant 2 & 1.78 & 1.23 & 4.35 \\
\hline Constant 3 & 2.37 & 1.92 & 4.74 \\
\hline Constant 4 & 3.59 & 2.61 & 6.46 \\
\hline Constant 5 & 4.53 & 3.74 & 7.30 \\
\hline Constant 6 & 7.18 & 6.98 & 9.92 \\
\hline
\end{tabular}


Table 4 continued

\begin{tabular}{llll}
\hline Variable & Belgium & Ireland & Slovenia \\
\hline Log-likelihood & $-1,641.3563$ & -758.66491 & $-1,166.0252$ \\
$R^{2}$ & .19 & .23 & .21 \\
$N$ & 1,380 & 570 & 886 \\
\hline
\end{tabular}

Note table figures are regression co-efficients with standard errors in parentheses. The dependent variable is the frequency of church attendance among individuals in the general population in each country

Source EVS 2008

$* p<.05, * * p<.01, * * * p<.001$

investigate these differences we included interaction terms for age as well as for country with each of the explanatory variables in our pooled models (see Model 6). We found that while age has basically no influence in Slovenia (co-efficient of -.00 ), it reduces the likelihood of church attendance in Ireland by a small amount (interaction effect of -.05). Compared to Slovenia, belief, ideological support of the church, and religious commitment have a significantly stronger influence on church attendance in Belgium and Ireland.

When we included interactions for country with the explanatory variables we found that the subjective importance of religion increases church attendance in Ireland compared to Slovenia. In Slovenia, importance of religion increases church attendance (co-efficient of 1.01) but it reduces the likelihood of church attendance in Ireland by a significant amount (interaction effect of -.38). These remaining country differences may reflect the influence of early religious socialization in Catholic schools or other cultural influences operative in different national settings.

This study's unexpected findings in relation to the research hypotheses set forth earlier, warrants further discussion. In all three countries belief has a statistically significant and positive effect on church attendance. One possible explanation for the relatively uniform effects of belief relates to the presence of non-Christian adherents. Regardless of the numerical size of the non-Christian population in the three regional settings, the presence of even some non-Christians in the national local environment may operate as an opposing identity category against which Christian commitment among Catholics is defined, and thus may help to augment the adherence of devotees to generic Christian ideas of God, sin, and life after death.

Second, features of Catholic theology and practice help explain the absence of variation in the influence of the ideological support variable on church attendance. Catholicism's strong emphasis on the integration of "faith and morals", following church teachings on personal morality, with "social action", focusing on the application of the church's body of social teachings to worldly affairs, encourages devotees to realize the faith-life linkage. It may be that whether this claims-making by the Catholic Church takes place in the context of co-operative or conflictual church-state interactions has less of a bearing on devotees' religious behavior than the fact that the church is actually willing at all to speak out, and take public positions, on important social and moral questions. 
Table 5 Pooled sample ordered logit hierarchical models of church attendance

\begin{tabular}{|c|c|c|c|c|c|c|}
\hline Variable & Model 1 & Model 2 & Model 3 & Model 4 & Model 5 & Model 6 \\
\hline \multicolumn{7}{|l|}{ Country $($ comp $=$ Slovenia $)$} \\
\hline Belgium & $\begin{array}{l}-.69 * * * \\
(.06)\end{array}$ & $\begin{array}{l}-.71 * * * \\
(.07)\end{array}$ & $\begin{array}{l}-.84 * * * \\
(.08)\end{array}$ & $\begin{array}{l}-.75^{* * * *} \\
(.08)\end{array}$ & $\begin{array}{l}-.75^{* * *} \\
(.08)\end{array}$ & $\begin{array}{l}16.29 \\
(10.20)\end{array}$ \\
\hline Ireland & $\begin{array}{l}1.13^{* * * *} \\
(.07)\end{array}$ & $\begin{array}{l}1.08^{* * *} \\
(.09)\end{array}$ & $\begin{array}{l}.29 * * \\
(.10)\end{array}$ & $\begin{array}{l}.54 * * * \\
(.10)\end{array}$ & $\begin{array}{l}.51 * * * \\
(.11)\end{array}$ & $\begin{array}{l}105.81^{* * *} \\
(12.90)\end{array}$ \\
\hline Age & & $\begin{array}{l}.00 \\
(.01)\end{array}$ & $\begin{array}{l}.02 \\
(.01)\end{array}$ & $\begin{array}{l}.02 * \\
(.01)\end{array}$ & $\begin{array}{l}.01 \\
(.01)\end{array}$ & $\begin{array}{l}-.00 \\
(.00)\end{array}$ \\
\hline $\mathrm{Age}^{2}$ & & $\begin{array}{l}.00 \\
(.00)\end{array}$ & $\begin{array}{l}-.00 \\
(.00)\end{array}$ & $\begin{array}{l}-.00 \\
(.00)\end{array}$ & $\begin{array}{l}-.00 \\
(.00)\end{array}$ & $\begin{array}{l}-.00 \\
(.00)\end{array}$ \\
\hline Gender & & $\begin{array}{l}-.19^{* *} \\
(.06)\end{array}$ & $\begin{array}{l}.10 \\
(.07)\end{array}$ & $\begin{array}{l}-.12 \\
(.07)\end{array}$ & $\begin{array}{l}.07 \\
(.07)\end{array}$ & $\begin{array}{l}.07 \\
(.07)\end{array}$ \\
\hline Not married & & $\begin{array}{l}-.21^{* *} \\
(.07)\end{array}$ & $\begin{array}{l}-.17 * \\
(.08)\end{array}$ & $\begin{array}{l}-.13 \\
(.08)\end{array}$ & $\begin{array}{l}-.12 \\
(.09)\end{array}$ & $\begin{array}{l}-.16 \\
(.09)\end{array}$ \\
\hline Number of children & & $\begin{array}{l}.06^{* *} \\
(.02)\end{array}$ & $\begin{array}{l}.02 \\
(.02)\end{array}$ & $\begin{array}{l}.01 \\
(.02)\end{array}$ & $\begin{array}{l}.01 \\
(.03)\end{array}$ & $\begin{array}{l}-.01 \\
(.06)\end{array}$ \\
\hline Some primary education & & $\begin{array}{l}.12 \\
(.25)\end{array}$ & $\begin{array}{l}.25 \\
(.26)\end{array}$ & $\begin{array}{l}.40 \\
(.26)\end{array}$ & $\begin{array}{l}.42 \\
(.28)\end{array}$ & $\begin{array}{l}.34 \\
(.28)\end{array}$ \\
\hline Some secondary education & & $\begin{array}{l}-.18 \\
(.24)\end{array}$ & $\begin{array}{l}.06 \\
(.24)\end{array}$ & $\begin{array}{l}.25 \\
(.25)\end{array}$ & $\begin{array}{l}.39 \\
(.27)\end{array}$ & $\begin{array}{l}.36 \\
(.27)\end{array}$ \\
\hline Some higher education & & $\begin{array}{l}-.09 \\
(.24)\end{array}$ & $\begin{array}{l}.20 \\
(.25)\end{array}$ & $\begin{array}{l}.43 \\
(.26)\end{array}$ & $\begin{array}{l}.56^{*} \\
(.28)\end{array}$ & $\begin{array}{l}.59^{*} \\
(.28)\end{array}$ \\
\hline Employment & & $\begin{array}{l}-.13 \\
(.08)\end{array}$ & $\begin{array}{l}-.05 \\
(.08)\end{array}$ & $\begin{array}{l}-.01 \\
(.08)\end{array}$ & $\begin{array}{l}.04 \\
(.09)\end{array}$ & $\begin{array}{l}-.00 \\
(.09)\end{array}$ \\
\hline Political Ideology & & $\begin{array}{l}.24 * * * \\
(.01)\end{array}$ & $\begin{array}{l}.18^{* * * *} \\
(.01)\end{array}$ & $\begin{array}{l}.16^{* * * *} \\
(.01)\end{array}$ & $\begin{array}{l}.13 * * * \\
(.02)\end{array}$ & $\begin{array}{l}.13^{* * * *} \\
(.02)\end{array}$ \\
\hline Belief & & & $\begin{array}{l}3.00 * * * \\
(.11)\end{array}$ & $\begin{array}{l}2.34 * * * \\
(.12)\end{array}$ & $\begin{array}{l}1.16^{* * *} \\
(.14)\end{array}$ & $\begin{array}{l}1.17^{* * *} \\
(.24)\end{array}$ \\
\hline Confidence in church & & & & $\begin{array}{l}.25 * * * \\
(.03)\end{array}$ & $\begin{array}{l}.19^{* * *} \\
(.04)\end{array}$ & $\begin{array}{l}.22 * * \\
(.07)\end{array}$ \\
\hline Church answers needs & & & & $\begin{array}{l}1.48 * * * \\
(.10)\end{array}$ & $\begin{array}{l}.93 * * * \\
(.11)\end{array}$ & $\begin{array}{l}.77 * * * \\
(.19)\end{array}$ \\
\hline Comfort from religion & & & & & $\begin{array}{l}-.86^{* * * *} \\
(.09)\end{array}$ & $\begin{array}{l}-.66^{* * * *} \\
(.17)\end{array}$ \\
\hline Importance of religion & & & & & $\begin{array}{l}.85^{* * *} \\
(.05)\end{array}$ & $\begin{array}{l}1.01 * * * \\
(.09)\end{array}$ \\
\hline Age* Belgium & & & & & & $\begin{array}{l}-.00 \\
(.00)\end{array}$ \\
\hline Age* Ireland & & & & & & $\begin{array}{l}-.05^{* * * *} \\
(.00)\end{array}$ \\
\hline Belief* Belgium & & & & & & $\begin{array}{l}.02 \\
(.32)\end{array}$ \\
\hline Confidence* Belgium & & & & & & $\begin{array}{l}-.08 \\
(.09)\end{array}$ \\
\hline
\end{tabular}


Table 5 continued

\begin{tabular}{|c|c|c|c|c|c|c|}
\hline Variable & Model 1 & Model 2 & Model 3 & Model 4 & Model 5 & Model 6 \\
\hline $\begin{array}{l}\text { Church answers needs* } \\
\text { Belgium }\end{array}$ & & & & & & $\begin{array}{l}.05 \\
(.25)\end{array}$ \\
\hline $\begin{array}{l}\text { Comfort from religion* } \\
\text { Belgium }\end{array}$ & & & & & & $\begin{array}{l}-.26 \\
(.22)\end{array}$ \\
\hline $\begin{array}{l}\text { Importance of religion* } \\
\text { Belgium }\end{array}$ & & & & & & $\begin{array}{l}-.17 \\
(.12)\end{array}$ \\
\hline Belief* Ireland & & & & & & $\begin{array}{l}.18 \\
(.40)\end{array}$ \\
\hline Confidence* Ireland & & & & & & $\begin{array}{l}-.02 \\
(.12)\end{array}$ \\
\hline $\begin{array}{l}\text { Church answers needs* } \\
\text { Ireland }\end{array}$ & & & & & & $\begin{array}{l}.59 \\
(.30)\end{array}$ \\
\hline $\begin{array}{l}\text { Comfort from religion* } \\
\text { Ireland }\end{array}$ & & & & & & $\begin{array}{l}-.48 \\
(.28)\end{array}$ \\
\hline $\begin{array}{l}\text { Importance of religion* } \\
\text { Ireland }\end{array}$ & & & & & & $\begin{array}{l}-.38 * * \\
(.14)\end{array}$ \\
\hline Constant 1 & -.60 & .93 & 2.35 & 3.26 & 1.84 & 1.59 \\
\hline Constant 2 & -.23 & 1.27 & 2.77 & 3.69 & 2.33 & 2.08 \\
\hline Constant 3 & .09 & 1.64 & 3.22 & 4.16 & 2.86 & 2.61 \\
\hline Constant 4 & .88 & 2.51 & 4.27 & 5.29 & 4.12 & 3.88 \\
\hline Constant 5 & 1.43 & 3.16 & 3.16 & 5.02 & 6.11 & 5.02 \\
\hline Constant 6 & 3.46 & 5.32 & 7.36 & 8.60 & 7.64 & 7.69 \\
\hline Log-likelihood & $-6,375.52$ & $-4,821.06$ & $-4,383.38$ & $-4,042.31$ & $-3,669.82$ & $-3,622.82$ \\
\hline$R^{2}$ & .04 & .07 & .15 & .18 & .23 & .24 \\
\hline$N$ & 3,871 & 3,092 & 3,061 & 2,926 & 2,836 & 2,836 \\
\hline
\end{tabular}

Note table figures are regression co-efficients with standard errors in parentheses. The dependent variable is the frequency of church attendance among individuals in the general population in each country

Source EVS 2008

$* p<.05, * * p<.01, * * * p<.001$

Third, the similarity in the influence of the importance of religion measure across the three cases suggests that because ethnicity is an important component of religious identity in each context (Martin 1978), though more so in Ireland and Slovenia owing to specific ethno-religious conflicts in each society, this ethnic Catholicity bolsters the commitment of respondents to their faith which, in turn, motivates them to attend church as an expression of this ethno-religious identification. This convergence between ethnic and religious identities may thus confound the effects of variation in "existential security" and socio-economic development noted by other scholars (Norris and Inglehart 2004) on church attendance. At least for these three Catholic countries, this "existential security" effect does not straightforwardly apply. Consistent with earlier research (Wilcox et al. 1993), this also suggests that students of religion would do well to consider the importance of the influence of religious identity, whether one is an ethnic Catholic 
or not, on church attendance rather than simply whether or not one nominally belongs to a certain religious tradition, believes in its core teachings, or supports its public positions.

With reference to the socio-demographic variables, the results in Table 4 show that age squared has statistically significant effects on church attendance in Belgium and Slovenia but not in Ireland. The curvilinear age effect in Belgium and Slovenia is likely due to the constraints of ill-health on church attendance among older people that make them less mobile, and physically able to attend church, as they age. Gender and number of children have statistically significant effects on church attendance in all three samples. Not married has statistically significant effects in Belgium and Ireland but not Slovenia. Being employed has a statistically significant effect on church attendance in Belgium only. The co-efficient for political ideology is positive and highly significant in all three samples.

\section{Conclusion}

This study formulated hypotheses about the influence of three distinct social correlates of church attendance and empirically tested these with reference to individual-level data from three Catholic countries representing different modal types of Catholicity.

As such, the study contributes to our sociological understanding of religiosity in Europe in general, and Catholicism in particular, at both a theoretical and empirical level. Empirically, by implementing an often-bypassed research strategy, this study helps overcome shortcomings of other studies of secularization. Some prior research correctly includes large numbers of country cases and formulates general theoretical claims that are extended to many religions and countries (Norris and Inglehart 2004) but an unfortunate limitation of this approach is that it typically excludes the use of qualitative comparative historical data and misses an opportunity to specify and attempt to answer more specific research questions relevant to a smaller pool of countries and to particular religious denominations. Other research focuses on indepth single-country explorations in which contextual case study is possible but cross-national comparison is lacking (Lužný and Navrátilová 2001; Karpov 1999). Studies involving a comparison of a few select countries can successfully avoid the shortcomings of each of these approaches.

At a theoretical level, we expected that the influence of the explanatory variables would vary across the country samples. However, we found that the factors which lead to increases or decreases in church attendance are basically the same for all three cases. The presence of some non-Christian adherents in the local national environment, aspects of Catholic doctrine and practice, and the congruence of ethnic and religious identities help explain these unexpected findings.

These conclusions should be interpreted, however, in light of two limitations. Because we rely on cross-sectional data, we are unable to judge the temporal sequencing of the social correlates and church attendance nor to assess the different mechanisms of secularization operative in the three settings and how these may change over time, an analysis requiring the use of longitudinal data. In addition, our 
dependent variable is based on self-reports of church attendance and prior research suggests that this may be subject to measurement error (Chaves and Stephens 2003), as people tend to over-report their religious behaviour. Viable alternative measures, such as data from daily time-expenditure diaries, may be less prone to reporting errors (Chaves and Stephens 2003).

Finally, the study of correlates of religious behavior is likely to continue to warrant the attention of students of religion in the future. We argue for the need to develop contextual-based interpretations of church attendance that are sensitive to historical configurations in unique settings, as the remaining country effects found in this study suggest important nationally-specific cultural factors, that are not accounted for by the correlates of religious behavior, may be relevant to explaining variation in church attendance. Given the importance of historical-contextual analyses of Catholicism, future research could usefully investigate regional variation in historic church-state interactions and how these potentially impact on confidence in the church, and thus on church attendance, in these regions.

Acknowledgments This study was supported by the European Commission under the 6th Framework Programme's Research Infrastructures Action (Trans-national Access contract RITA 026040) hosted by IRISS-C/I at CEPS/INSTEAD, Differdange, Luxembourg, and a visit to the European Centre for Analysis in the Social Sciences (ECASS) at the Institute for Social and Economic Research, University of Essex, UK, supported by the Access to Research Infrastructures action under the EU Improving Human Potential Programme. The author would like to thank the three anonymous reviewers for their very helpful comments on an earlier version of this paper.

\section{References}

Aarts, Olav, Ariana Need, Manfred Te Grotenhuis, and Nan Dirk De Graaf. 2008. Does believing accompany belonging? Correlations and trends in Western Europe and North America between 1981 and 2000. Review of Religious Research 50: 16-34.

Bezjak, Sonja. 2012. Catholic women religious vocations in the twentieth century: The Slovenian case. Review of Religious Research 54 (2): 157-174.

Bibby, Reginald W., and Merlin B. Brinkerhoff. 1974. Sources of religious involvement: Issues for future empirical investigation. Review of Religious Research 15: 71-79.

Cava, Ralph Della. 1997. Religious resource networks: Roman Catholic philanthropy in central and eastern Europe. In Transnational religion: Fading states, ed. S.H. Rudolph, and J. Piscatori, 173-211. Boulder: Westview Press.

Chaves, Mark. 1994. Secularization as declining religious authority. Social Forces 72(3): 749-774.

Chaves, Mark, and Laura Stephens. 2003. Church attendance in the United States. In Handbook of the sociology of religion, ed. M. Dillon, 85-95. Cambridge: Cambridge University Press.

Cornwall, Marie. 1987. The social bases of religion: A study of factors influencing religious belief and commitment. Review of Religious Research 29: 44-56.

Cornwall, Marie. 1989. The determinants of religious behavior: A theoretical model and empirical test. Social Forces 68: 572-592.

Črnič, Aleš, and Gregor Lesjak. 2003. Religious freedom and control in independent Slovenia. Sociology of Religion 64: 349-366.

Dillon, Michele. 1996. Cultural differences in the abortion discourse of the Catholic Church: Evidence from four countries. Sociology of Religion 57: 25-36.

Dobbelaere, Karel, and Liliane Voyé. 1990. From pillar to postmodernity: The changing situation of religion in Belgium. Sociological Analysis 51: S1-S13.

Dobbelaere, Karel. 1988. Secularization, pillarization, religious involvement, and religious change in the low countries. In World Catholicism in transition, ed. T.M. Gannon, 80-115. New York: Macmillan. 
Dobbelaere, Karel. 1995. The surviving dominant Catholic church in Belgium: A consequence of its popular religious practices? In The post-war generation and establishment religion: Cross-cultural perspectives, ed. W.C. Roof, J.W. Carroll, and D.A. Roozen, 171-190. Boulder: Westview Press.

Dobbelaere, Karel. 1999. Towards an integrative perspective of the processes related to the descriptive content of secularization. Sociology of Religion 60 (3): 229-247.

Dolenc, Ervin. 1994. Culture, politics, and Slovene identity. In Independent Slovenia: Origins, movements, prospects, ed. J. Benderly, and E. Kraft, 69-92. New York: St. Martin's Press.

Dragos, Sreco. 2009. Religious freedom in Slovenia. In Quo vadis Eastern Europe? Religion, state, society and inter-religious dialogue after communism, ed. Ines Murzaku, 147-164. Bologna: University of Bologna Press.

Fahey, Tony. 1992. Catholicism and industrial society in Ireland. In The development of industrial society in Ireland, ed. J.H. Goldthorpe, and C.T. Whelan, 241-264. Oxford: Oxford University Press.

Fiamengo, Ante. 1972. Yugoslavia. In Western religion: A country by country sociological inquiry, ed. H. Mol, 587-599. The Hague: Mouton.

Fishman, Robert M., and Keely Jones. 2007. Civic engagement and church policy in the making of religious vocations: Cross-national variation in the evolution of priestly vocations. In Vocation and social context, ed. G. Giordan, 127-152. Leiden: Brill.

Fox, Renée C. 1982. Is religion important in Belgium? Archives Européennes de Sociologie/European Journal of Sociology XXIII: 3-38.

Gannon, Thomas M. (ed.). 1988. World Catholicism in transition. London: Macmillan.

Gautier, Mary L. 1997. Church attendance and religious belief in postcommunist societies. Journal for the Scientific Study of Religion 36: 289-296.

Gorski, Philip S., and Ateş Altinordu. 2008. After secularization? Annual Review of Sociology 34: 55-85.

Gorski, Philip S. 2003. Historicizing the secularization debate: An agenda for research. In Handbook of the sociology of religion, ed. Michele Dillon, 110-122. Cambridge: Cambridge University Press.

Greeley, Andrew M. 2003. Religion in Europe at the end of the second millenium: A sociological profile. New Brunswick: Transaction Publishers.

Greeley, Andrew. 2004. The Catholic revolution. Berkeley: University of California Press.

Hoge, Dean R. 1986. Interpreting change in American Catholicism: The river and the floodgate. Review of Religious Research 27 (4): 289-299.

Houtart, François. 1970. Belgium. In Western religion: A country by country sociological inquiry, ed. H. Mol, 67-82. The Hague: Mouton.

Inglis, Tom. 1998. Moral monopoly: The rise and fall of the Catholic church in modern Ireland, 2nd rev. Dublin: University College Dublin Press.

Jelen, Ted G., and Clyde Wilcox. 1998. Context and conscience: The Catholic church as an agent of political socialization in western Europe. Journal for the Scientific Study of Religion 37 (1): 28-40.

Karpov, Vyacheslav. 1999. Religiosity and political tolerance in Poland. Sociology of Religion 60: 387-402.

Kelley, Jonathon, and Nan Dirk De Graaf. 1997. National context, parental socialization, and religious belief: Results from 15 nations. American Sociological Review 62: 639-659.

Keogh, Dermot. 2007. The Catholic Church in Ireland since the 1950s. In The Church confronts modernity: Catholicism since 1950 in the United States, Ireland, and Quebec, ed. L. Woodcock Tentler, 93-149. Washington, DC: The Catholic University of America.

Kerševan, Marko. 1993. Ambivalence of religious revitalization in post-socialist societies. Social Compass 40 (1): 123-133.

Lüchau, Peter. 2007. By faith alone? Church attendance and Christian faith in three European countries. Journal of Contemporary Religion 22: 35-48.

Lužný, Dušan, and Jolana Navrátilová. 2001. Religion and secularization in the Czech Republic. Czech Sociological Review 9 (1): 85-98.

Manuel, Paul Christopher, Lawrence C. Reardon, and Clyde Wilcox. 2006. The Catholic church and the nation-state: Comparative perspectives. Washington, DC: Georgetown University Press.

Martin, David. 1978. A general theory of secularization. Oxford: Basil Blackwell.

Martin, David. 1994. The fall of Rome: Today's Catholic predicament. Religion 24 (2): 95-102.

Mooney, Margarita. 2009. Faith makes us live: Surviving and thriving in the Haitian diaspora. Berkeley: University of California Press.

Meulemann, Heiner. 2004. Enforced secularization, Spontaneous revival? European Sociological Review 20: 47-61. 
Need, Arian, and Geoffrey Evans. 2001. Analysing patterns of religious participation in post-communist Eastern Europe. British Journal of Sociology 52: 229-248.

Norris, Pippa, and Ronald Inglehart. 2004. Sacred and secular: Religion and politics worldwide. Cambridge: Cambridge University Press.

Ramet, Sabrina P., and Danica Fink-Hafner (eds.). 2006. Democratic transition in Slovenia: Value transformation, education, and media. College Station: Texas A\&M University Press.

Ramet, Pedro. 1985. Factionalism in church-state interaction: The Croatian Catholic church in the 1980s. Slavic Review 44 (2): 298-315.

Ramet, Sabrina. 2002. Balkan babel: The disintegration of Yugoslavia from the death of Tito to the fall of Milošević. Boulder: Westview Press.

Roberts, Michael K., and James D. Davidson. 1984. The nature and sources of religious involvement. Review of Religious Research 25: 334-350.

Schieman, Scott. 2010. Socioeconomic status and beliefs about god's influence in everyday life. Sociology of Religion 71 (1): 25-51.

Schnittker, Jason. 2001. When is faith enough? The effects of religious involvement on depression. Journal for the Scientific Study of Religion 40: 393-411.

Smrke, Marjan. 2008. The Slovenes and the Catholic church. The reflections of a sociologist. In Separation of church and state in Europe with views on Sweden, Norway, the Netherlands, Belgium, France, Spain, Italy, Slovenia and Greece, ed. Fleur de Beaufort, Ingemund Hägg, and Patrick van Schie. Brussels: European Liberal Forum. Accessed 20 Aug 2012.

Smrke, Marjan, and Tatjana Rakar. 2006. Religious education in Slovenia. In Religion and pluralism in education: Comparative approaches in the Western Balkans, eds. Kuburić, Zorica, and Moe, Christian, 9-38. Novi Sad: CEIR (The Centre for Empirical Researches on Religion). http://kotornetwork.info/research/joint/2005/RelPlurEdu.pdf; http://kotor-network.info/index.htm.

Stark, Rodney, and Roger Finke. 2000. Catholic religious vocations: Decline and revival. Review of Religious Research 42 (2): 125-145.

Stark, Rodney. 1998. Catholic contexts: Competition, commitment and innovation. Review of Religious Research 39 (3): 197-208.

Swatos, William H., and Daniel Olson. 2000. The secularization debate. Boston: Rowman \& Littlefield.

Tabak, Melanie A., and Kristin D. Mickelson. 2009. Religious service attendance and distress: The moderating role of stressful life events and race/ethnicity. Sociology of Religion 70 (1): 49-64.

Tschannen, Olivier. 1991. The secularization paradigm: A systematization. Journal for the Scientific Study of Religion 30 (4): 395-415.

United Nations Development Programme. 2011. Human development report 2011. New York: Palgrave Macmillan.

Vidić, Rastko. 1962. The position of the church in Yugoslavia. Beograd: Publicističko-Izdavački Zavod Jugoslavija.

Wilcox, Clyde, Ted G. Jelen, and David C. Leege. 1993. Religious group identifications: Toward a cognitive theory of religious mobilization. In Rediscovering the religious factor in American politics, ed. D.C. Leege, and L.A. Kellstedt, 72-99. New York: M. E. Sharpe. 